\title{
Os febianos: experiência, consciência e agência dos trabalhadores brasileiros convocados para a guerra na Força Expedicionária Brasileira - FEB $(1943$ - 1945)
}

The febianos: experience, consciousness and agency of Brazilian workers called to war in the Brazilian Expeditionary Force - BEF (1943 - 1945)

\section{Frederico Soares Ribeiro*}

Resumo: Este artigo analisa as características de uma identidade coletiva surgida entre parte dos civis recrutados para a Força Expedicionária Brasileira (FEB) e algumas de suas tentativas de agência durante a campanha da Itália. As novas práticas vivenciadas no âmbito desse coletivo eram muito diferentes das práticas adotadas no Exército brasileiro. Em episódios de indisciplina ou de utilização dos instrumentos construídos coletivamente, como o jornal de trincheira ' $E$ a Cobra Fumou!, buscamos evidenciar o protagonismo dos febianos em relação ao comando, composto por militares de carreira do Exército brasileiro.

Palavras-chave: Força Expedicionária Brasileira; Exército de Caxias; Segunda Guerra Mundial.

Abstract: This article analyzes the characteristics of a collective identity that emerged among part of the civilians recruited for the Brazilian Expeditionary Force (BEF) and some of their agency attempts during the Italian campaign. The new practices experienced within this collective were very different from the practices adopted in the Brazilian Army. In episodes of indiscipline or in the use of collectively constructed instruments, such as the trench newspaper - E a Cobra Fumou! - we seek to highlight the protagonism of the febianos in relation to the command, composed of career soldiers of the Brazilian Army.

Keywords: Brazilian Expeditionary Force; Army of Caxias; Second World War.

\footnotetext{
Mestre em História, pela Universidade Federal Rural do Rio de Janeiro (UFRRJ). Docente de História na Secretaria de Estado de Educação, do Rio de Janeiro, e na Secretária Municipal de Educação de Piraí - RJ. E-mail: fred.joaomaia@gmail.com. ORCID: https://orcid.org/0000-0002-0413-225X.
} 


\section{Introdução}

Em agosto de 1942, o governo Getúlio Vargas declarou guerra à Alemanha e Itália. Em 1943, foi criada a Força Expedicionária Brasileira (FEB). Milhares de civis brasileiros, trabalhadores de diferentes lugares e profissões, foram convocados para integrá-la e tiveram que, abruptamente, adaptar-se à vida rígida da hierarquia e da disciplina dos regulamentos militares. Esses trabalhadores, que se tornaram soldados, eram comandados por militares profissionais do Exército Brasileiro. Esses oficiais de carreira, com formação na Escola Militar, foram designados para o comando da FEB e todas as suas unidades militares.

Este artigo, adaptado de um texto anterior, ${ }^{1}$ pretende demonstrar características da nova identidade coletiva surgida entre esses trabalhadores civis que se tornaram expedicionários e lutaram pela FEB na Campanha da Itália. Em diálogo com a historiografia sobre a FEB, como testemunhos e uma série de Certificados de Reservistas, foi possível traçar um perfil desses expedicionários.

Embora seja perfeitamente possível compreender a FEB e seus membros, constituídos por militares profissionais e civis convocados, como trabalhadores e pertencentes ao mundo do trabalho, neste artigo optamos por fazer um cruzamento entre a antropologia dos militares e a história social do trabalho. Como observamos adiante, para os antropólogos a identidade militar tem como um de seus pilares a distinção em relação ao mundo civil. ${ }^{2}$ Nesse sentido, buscamos demonstrar como a Segunda Guerra Mundial foi um momento de ruptura na fronteira entre o mundo militar e o mundo civil, com o ingresso de milhares de trabalhadores convocados pelo exército.

Os testemunhos e outras fontes também nos deram acesso a experiências de adaptação à vida militar, à difícil rotina no front, à convivência com os outros exércitos aliados na Itália, basicamente compostos de trabalhadores civis recrutados para o mesmo fim. Com base nessas experiências buscamos compreender como nasceu essa identidade coletiva febiana, quais eram seus valores e ideais. Na parte final deste estudo, oferecemos exemplos de como esses homens se organizaram e protagonizaram ações que desafiavam o tradicional sentido da hierarquia militar.

Este artigo é uma adaptação do segundo capítulo da minha dissertação de mestrado em História (O Exército de Caxias e o Exército da FEB: história das relações entre estabelecidos e outsiders no Exército Brasileiro (1942 - 1945), Universidade Federal Rural do Rio de Janeiro - UFRRJ, 2017).

2 Entre os autores que apontam a distinção entre mundo civil e mundo militar como um fundamento da identidade militar, encontram-se Celso Castro, Piero Leirner, Lauriane Porto Albertini, entre outros. Adiante, retomamos este debate, de maneira mais precisa na seção Cruzando fronteiras: quando o mundo do trabalho invade a caserna. 


\section{Um perfil dos expedicionários}

A convocação e seleção de recrutas para construir uma força combatente capaz de lutar na guerra moderna foi uma tarefa hercúlea para o comando do Exército Brasileiro (EB). Enquanto o EB estava organizado a partir da doutrina militar francesa, a primeira Divisão de Infantaria Expedicionária (DIE) ${ }^{3}$ estava sendo organizada de acordo com a doutrina militar dos EUA. A transição do modelo inspirado na doutrina francesa para o modelo estadunidense não se deu de maneira simples. Vários dos serviços e especialidades previstas nos manuais militares estadunidenses não tinham correspondente ou eram completamente diferentes do sistema usado no EB. Tanto que o Ministro da Guerra, general Dutra afirmou que "para não haver uma brusca modificação em nossa estrutura fundamental, somente as unidades da $1^{\text {a }}$ DIE [...] tomaram o efetivo que denominamos tipo FEB". E que "havendo profunda diferença entre os dois quadros - o nacional e o norte-americano - não julgamos aconselhável fazer a transformação do efetivo de todas as unidades". ${ }^{4}$ Dutra reconheceu essa dupla organização, uma antiga à francesa e uma moderna, inspirada na estadunidense como uma anomalia. ${ }^{5}$

O historiador Francisco César Alves Ferraz assinalou que foram realizadas 107.609 inspeções de saúde e reprovados 23.326 convocados e que o número de voluntários foi pequeno: pouco mais de mil homens, em um contingente total de mais de 25 mil selecionados. ${ }^{6}$

Para traçar um breve perfil desses expedicionários, recorremos às fontes do Arquivo Histórico do Exército (AHEx), onde conseguimos consultar todas as cópias dos Certificados de Reservistas disponíveis. A amostragem foi de 1.162 certificados, todos de praças, reunidos em seis livros e na caixeta 185, o que remete a aproximadamente $5 \%$ do efetivo de praças da FEB. Baseamos essa estimativa no efetivo de praças da FEB, 23.640, apontada nas notas do livro de memórias do general Mascarenhas de Moraes, comandante da FEB. ${ }^{7}$

$\mathrm{Na}$ amostra, observamos que menos de $5 \%$ eram voluntários, oriundos de profissões urbanas, sendo a maior parte do voluntariado constituída de comerciários.

3 A DIE era composta por Quartel General e Tropa Especial, Artilharia Divisionária, Infantaria Divisionária, Especialistas. As unidades militares estavam subordinadas a algum desses comandos. Por exemplo: os regimentos de infantaria eram parte da Infantaria Divisionária. No total, incluindo oficiais e praças, os órgãos divisionários contavam com um efetivo de 14.275 homens. Somando os órgãos não divisionários, a FEB era composta por mais de 25 mil homens.

4 Arquivo Histórico do Exército (AHEx), Relatório do Ministro da Guerra de 1944. p. 20.

5 Ibidem, p. 245.

6 FERRAZ, Francisco César Alves. Os brasileiros e a Segunda Guerra Mundial. Rio de Janeiro: Jorge Zahar, 2005. p. 48-49.

7 MORAES, João Baptista Mascarenhas de. A FEB pelo seu comandante. Rio de Janeiro: Biblioteca do Exército Ed., 2005. p. 38-40. 
O historiador Karl Schurster afirmou que "o alistamento militar utilizou-se de técnicas da propaganda política para melhor convencimento das obrigações do povo para com o país". ${ }^{8}$ Luciano Meron realçou que, além do próprio governo, a sociedade civil passou a encorajar o esforço de guerra:

\begin{abstract}
A mobilização contra as nações do Eixo e o movimento a favor dos aliados tornara-se um importante veículo de ação popular, em especial as classes médias [...] Os estudantes tornaram-se o meio de ligação dos grupos que se articulavam [...] Surgem associações civis com o intuito de mobilizar a sociedade baiana em prol dos aliados, contra os fascistas e a favor da democracia [...] a faculdade de Direito, a faculdade de Medicina, a Escola Politécnica e o Ginásio da Bahia foram centros irradiadores do movimento pró aliados. Em maio de 1942, seria fundada a Comissão Central Estudantil pela Defesa Nacional e Pró Aliados [...] associações como essa surgiriam nas principais cidades do país, demonstrando que, pelo menos nos centros urbanos e nas classes médias havia um interesse pela guerra e por uma atuação política ativa junto às ações do governo frente ao conflito mundial que crescia. Como ator de muitas dessas mobilizações políticas estava o PCB. Mesmo na clandestinidade o Partido Comunista estava envolvido e ativo junto a esses movimentos [...] ajudando a articular as associações que englobavam estudantes, professores, operários, profissionais liberais. 9
\end{abstract}

A atuação do Partido Comunista do Brasil (PCB) em relação ao voluntariado também foi lembrada através do testemunho do oficial do exército Kardec Lemme, militante clandestino do Partido e que servia no $10^{\circ}$ Regimento de Infantaria em Mato
Apolônio [...], ele foi lá, desceu em Bela Vista em um aviãozinho, um correio que fazia aquela linha, ele conseguiu viagem nela, foi lá e chegou lá uma tarde, alguém me disse: "Ó, tem um senhor, quer falar com você". Ele, eu estava em um bar da cidade, esperando que ele aparecesse e ele apareceu. A conversa dele foi apenas uma decisão do partido. "Bom, a guerra está aí, você não ficar aqui namorando paraguaia, passeando de cavalinho branco para nada, é o momento". Isso é conversa dele: "É o momento que você tem a guerra como um fator decisivo para a sua profissão, você é militar, está com as Forças Armadas, já está com visão de ser General, então, você não ficar aqui comendo e dormindo e deixando que nós façamos a guerra por nossa conta, então, se você tiver vontade e quiser, se apresente voluntário. ${ }^{10}$

8 SCHURSTER, Karl apud SILVA, Francisco Carlos Teixeira da et. al. (org.). O Brasil e a Segunda Guerra Mundial. Rio de Janeiro, 2010, p. 462.

9 MERON, Luciano Bastos. Memórias do front: relatos de guerra de veteranos da FEB. 2009. Dissertação (Mestrado em História) - Faculdade de Filosofia e Ciências Humanas, Universidade Federal da Bahia, Salvador, 2009. p. 27.

10 Depoimento de Kardec Lemme à Comissão Nacional da Verdade, página 15. Disponível em: http://cnv.memoriasreveladas.gov.br/images/pdf/depoimentos/Kardec_Lemme__RDK_19.06.2013.pdf. Acesso em: 18 jul. 2019. 
Vários comunistas integraram a FEB, como Salomão Malina, Jacob Gorender e Pedro Paulo Sampaio de Lacerda, entre outros. ${ }^{11}$ Ressalto que os comunistas citados não estavam na amostra, mas reforçam o aspecto do engajamento do PCB na luta antinazifascista, percebendo a FEB como uma forma de levar comunistas brasileiros ao front. Não podemos desprezar a influência desses atores junto aos expedicionários da FEB.

De qualquer forma, os autores e testemunhos acima ressaltam a ideia de que a sociedade brasileira se organizou junto ao governo para o esforço de guerra. Por mais que o voluntariado não tenha sido grande, a resposta às convocações por parte dos reservistas foi. A FEB foi composta por uma grande variedade de segmentos da sociedade brasileira. De acordo com a amostra, os expedicionários eram de 21 diferentes estados da federação, sendo $56 \%$ da região Sudeste, onde estavam os Regimentos de Infantaria designados para a FEB. A faixa etária englobava homens de 17 a 37 anos, sendo que aproximadamente $82 \%$ deles tinham entre 21 e 26 anos.

\section{Gráfico 1}

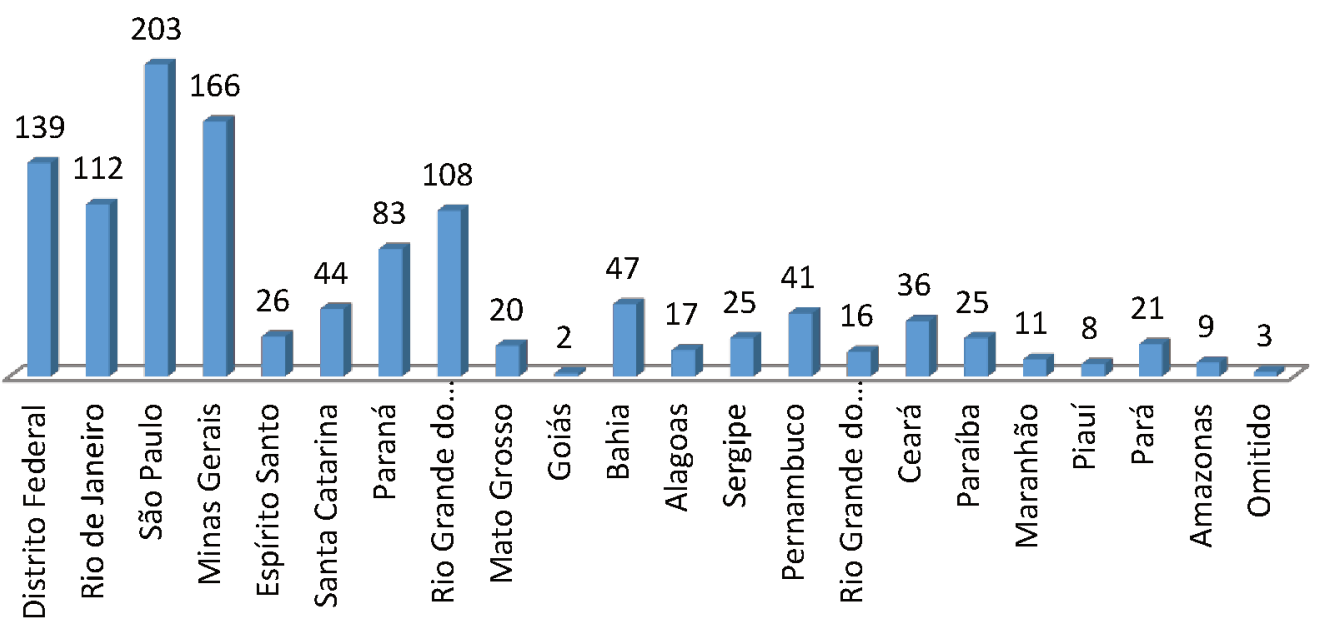

Fonte: AHEx, acervo FEB, baseado em uma série de 1.162 Certificados de Reservista

A idade dos soldados revela a dificuldade de conseguir recrutar combatentes aptos e especialistas, tendo que recorrer à convocação sucessiva de reservistas de anos anteriores, chegando a recrutar reservistas de até 37 anos.

11 PIMENTEL, Carlos Henrique Lopes. A esquerda militar no Brasil: os veteranos comunistas da FEB. Veredas da História, ano 3, n. 2, p. 1-20, 2010. 


\section{Gráfico 2}

Idade dos expedicionários

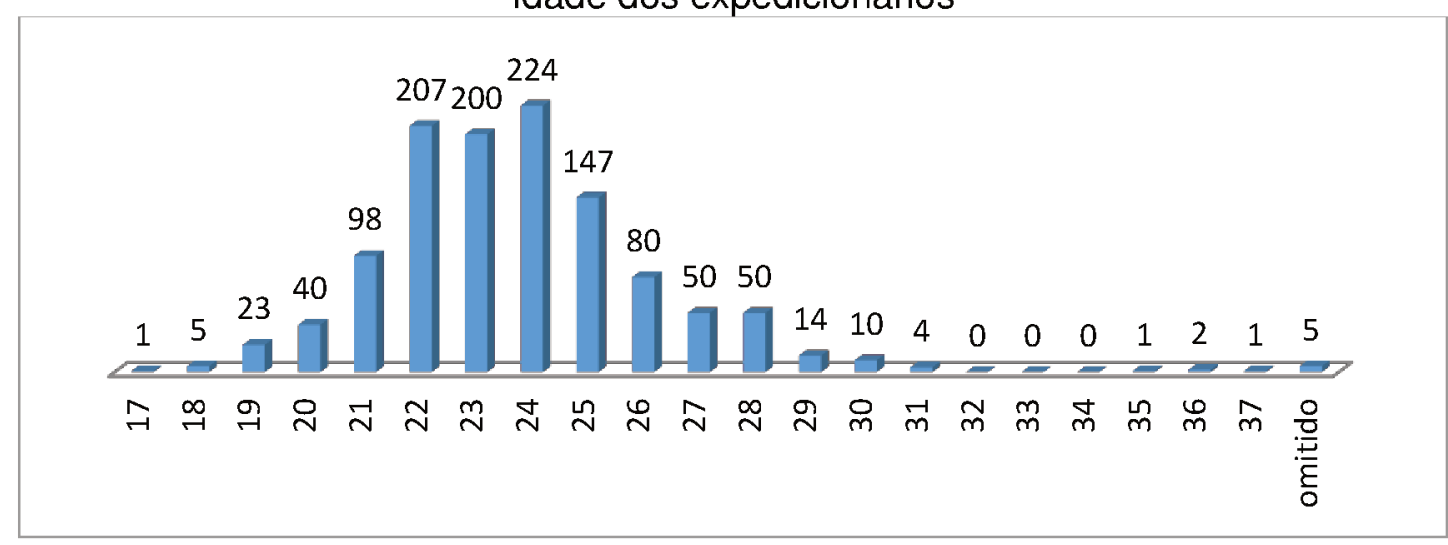

Fonte: AHEx, acervo FEB, baseado em uma série de 1.162 Certificados de Reservista

No que se refere à profissão que exerciam antes da convocação, foi observada uma grande diversidade na amostra. As profissões ligadas a atividades do campo somavam 289 praças, equivalente a aproximadamente $25 \%$ da amostra. As profissões urbanas, $75 \%$ do total, e apresentavam uma diversidade muito grande.

\section{Gráfico 3}

Profissão dos expedicionários

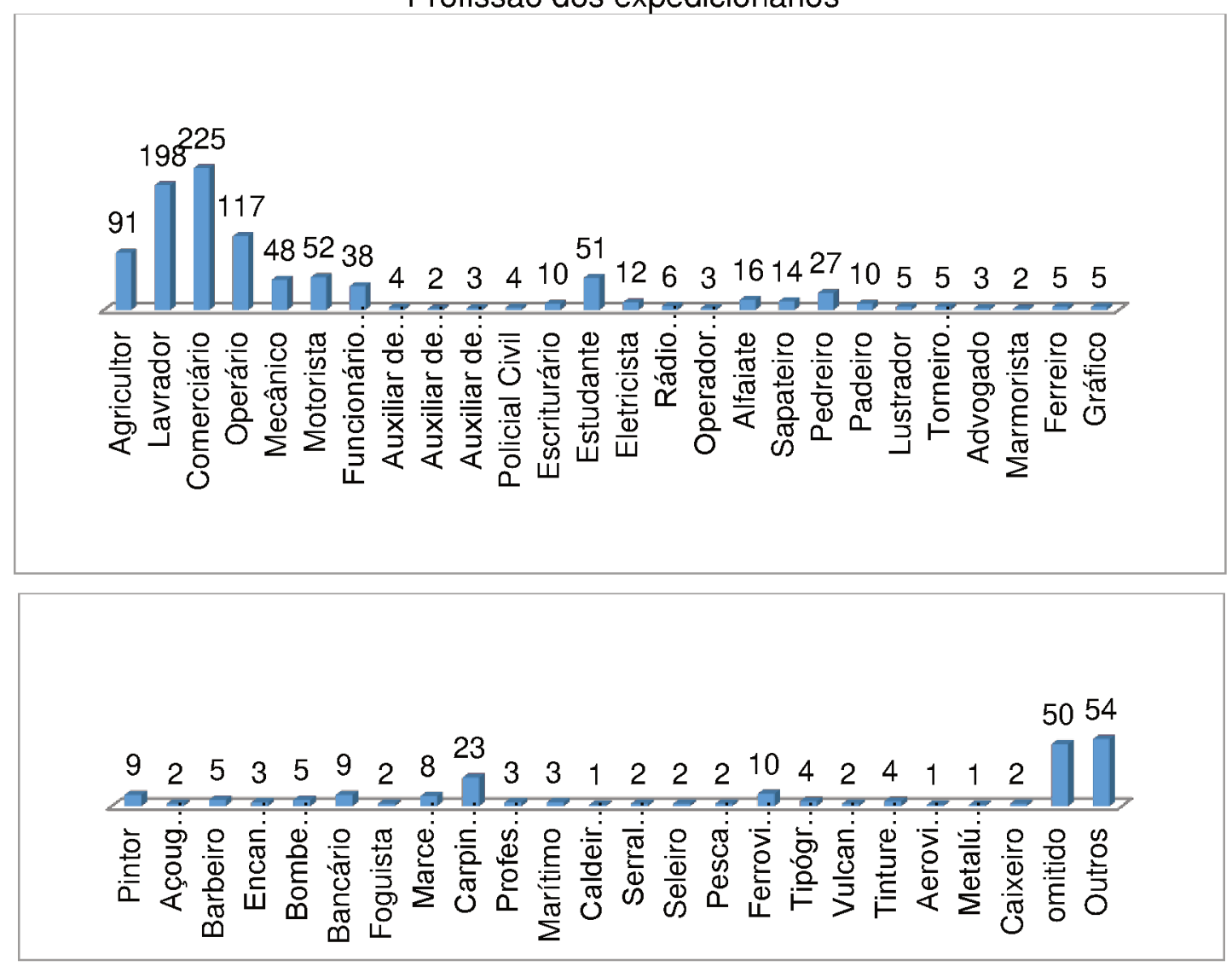

Fonte: AHEx, acervo FEB, baseado em uma série de 1.162 Certificados de Reservista 
Portanto, é possível afirmar que foram incorporados à FEB civis com experiências profissionais muito distintas entre si. Além disso, não se pode desprezar que esses homens trouxeram consigo diferentes formas de ver o mundo, de ideias de disciplina ou hierarquia profissional, pois havia aqueles que trabalhavam para si próprios, havia profissionais liberais, operários, comerciários, ferroviários, bancários, funcionários públicos, estudantes, pessoas que podiam estar ligadas a entidades de classe, membros de associações, grêmios e até mesmo de partidos políticos. Todos eles, em maior ou menor grau, estavam acostumados a vivenciar negociações e tensões do dia a dia com seus patrões, seja por questões de horário de trabalho, seja por salário, seja por cobranças por produtividade. Eram pessoas que, de súbito, foram obrigadas a vivenciar a rigidez disciplinar do Exército, sem se despir de suas experiências como trabalhadores, ao vestir uma farda.

Também foi possível abordar aspectos raciais a partir dos formulários. É necessário ressaltar que este era um campo preenchido à mão pelo agente emissor do certificado, não tendo sido possível precisar se esse preenchimento resultava de autodeclaração ou da observação do agente. A variedade de classificações para a cor da pele encontrada nos formulários foi grande: branca, parda, parda clara, parda escura, morena e preta. A amostra revelou que $66 \%$ dos expedicionários na amostra eram brancos.

\section{Gráfico 4}

Cor da pele dos expedicionários

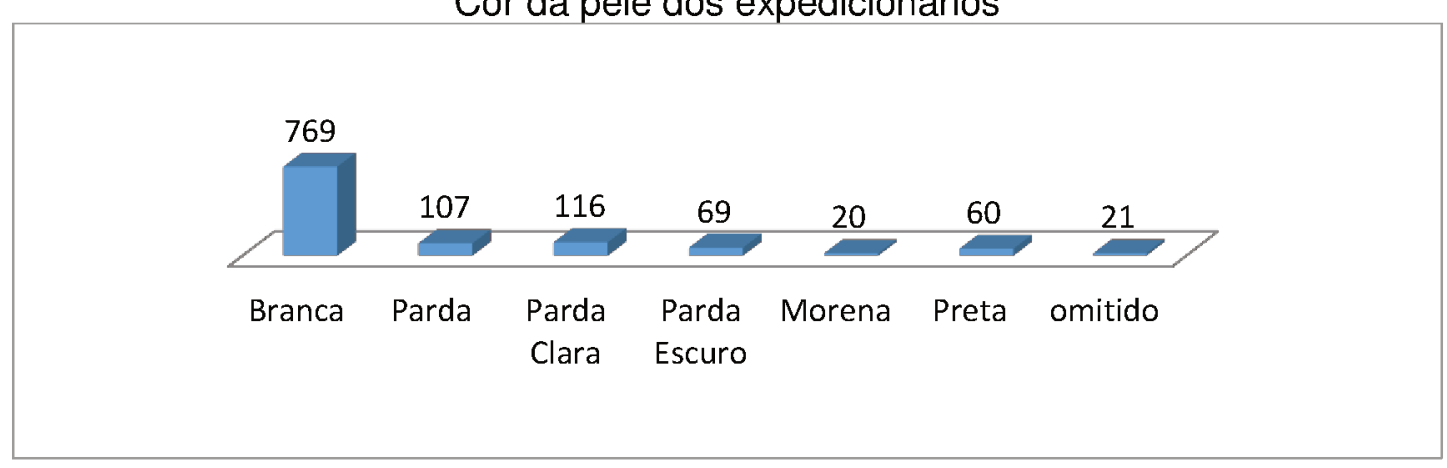

Fonte: AHEx, acervo FEB, baseado em uma série de 1.162 Certificados de Reservista

Nesta pesquisa, relacionamos todas as profissões dos expedicionários com a cor da pele. Devido à extensão das informações, não foi possível apresentar a tabela aqui no corpo do artigo e, sim, em anexo ao artigo. Independentemente da cor da pele, profissões de baixa especialização ou qualificação compunham a maioria da amostra, mas evidenciamos que as profissões com maior nível de qualificação e especialização eram de pessoas brancas. Como exemplo, podemos recorrer ao gráfico das profissões dos expedicionários apresentado anteriormente, para afirmar 
que todos advogados, policiais civis, bancários e escriturários encontrados na amostra eram brancos.

Além disso, poucas pessoas de pele parda clara apresentavam formação profissional especializada, como é o caso de um professor. Nas pessoas com pele parda, parda escura, morena e preta predominam profissões semiespecializadas ou não especializadas, com pouquíssimas exceções. Um exemplo é o caso dos estudantes adultos da amostra, que possivelmente estavam em busca de formação profissional. Foram encontrados 51 estudantes, sendo 47 brancos, 3 de pele parda clara e um único estudante de pele preta. A amostra apontou uma baixíssima quantidade de analfabetos entre os recrutados (6\%), mas não há como afirmar a escolaridade dos expedicionários.

Todos esses dados profissionais permitiram concluir que as oportunidades de estudar e se especializar profissionalmente eram encontradas, com maior frequência, pelas pessoas brancas ou de pele parda clara, evidenciando a desigualdade racial como um elemento estruturante da sociedade brasileira, naquele momento.

Essa conclusão é reforçada em outros estudos sobre o mesmo contexto histórico. Ao estudar as relações raciais na cidade de Volta Redonda - RJ, o historiador Leonardo Ângelo da Silva apresenta a seguinte tabela, elaborada por Dinius, sobre os trabalhadores da Companhia Siderúrgica Nacional (CSN):

\section{Tabela 1}

Qualificação por cor dos trabalhadores contratados 1941-1946

\begin{tabular}{|c|c|c|c|c}
\multirow{2}{*}{ Tez } & \multicolumn{3}{|c|}{ Nivel de Qualificação } & \multirow{2}{*}{ Total } \\
\cline { 2 - 4 } & Especializado & $\begin{array}{c}\text { Semi- } \\
\text { Especializado }\end{array}$ & $\begin{array}{c}\text { Não- } \\
\text { Especializado }\end{array}$ & \\
\hline Branco & $40,1 \%$ & $43,8 \%$ & $26,4 \%$ & $30,7 \%$ \\
\hline Negro & $24,7 \%$ & $21,7 \%$ & $37,8 \%$ & $33,7 \%$ \\
\hline Pardo & $35,1 \%$ & $34,5 \%$ & $35,8 \%$ & $35,5 \%$ \\
\hline Total & $\mathbf{1 0 0 , 0} \%$ & $\mathbf{1 0 0 , 0} \%$ & $\mathbf{1 0 0 , 0} \%$ & $\mathbf{1 0 0 , 0} \%$ \\
\hline
\end{tabular}

Fonte: Dinius (2004, p.182, apud SILVA, 2019, p. 41).

O historiador afirma que:

Segundo a tabela de Dinius, somando-se os trabalhadores que ele identifica como negros e pardos, concluiríamos que $69 \%$ dos trabalhadores envolvidos com a construção da CSN eram negros e, se olharmos o número de trabalhadores não-especializados, ou seja, os que trabalhavam em situações mais pesadas, esse número sobe para $73,6 \%$. A lógica da herança das desvantagens seguia, os dados eram brutalmente diferenciados para pessoas de origens raciais diferentes. ${ }^{12}$

12 SILVA, Leonardo Ângelo da. Volta Redonda em preto e branco: trabalho, desenvolvimentismo e relações raciais (1946 - 1988). 2019. Tese (Doutorado em História) - Instituto de Ciências Humanas e Sociais, Instituto Multidisciplinar, Universidade Federal Rural do Rio de Janeiro, Nova Iguaçu, 2019. p. 41. 
Leonardo Ângelo também recorre ao estudo de Costa Pinto, que, nos anos de 1940, revela a seguinte composição racial entre estudantes matriculados no nível educacional elementar, grau médio e nível superior, respectivamente: brancos $83,50 \%$, 93,81 e $96,37 \%$; pretos - 3,88\%, 0,85 e 0,38\%; e pardos - 12,53\%, 5,24\% e $3,12 \% .{ }^{13} \mathrm{O}$ historiador foi assertivo ao concluir que "a constante, além da subrepresentação dos negros em todos os segmentos, é o aumento de percentuais para brancos e a redução para pardos e, principalmente, pretos, à medida que avança o grau de escolaridade". ${ }^{14}$

Podemos dizer que a baixa escolaridade e baixa especialização da mão de obra foram comuns também nas décadas seguintes, como aponta Leôncio Martins Rodrigues, em seu estudo com trabalhadores da indústria automotiva, na Grande São Paulo da década de 1960:

Entre todos entrevistados não se encontrou nenhum trabalhador que tivesse grau de instrução superior à ginasial. Apenas $4 \%$ dos operários declararam possuir ginásio completo. Entre os ferramenteiros a proporção foi de $9 \%$. Por outro lado, $6 \%$ dos operários não possuíam nenhuma instrução [...] Entre os trabalhadores recentemente chegados de áreas tradicionais, a porcentagem dos que afirmaram não possuir nenhuma instrução atingiu $10 \%[. .$.$] O baixo nível de instrução geral, acompanha-se,$ pois, de deficiente formação profissional e especializada. Apenas $9 \%$ dos operários cursaram escolas técnicas, sendo que $40 \%$ aprenderam a profissão na própria empresa automobilística. ${ }^{15}$

No caso das relações raciais na FEB, existia outro ponto agravante. No período imediatamente anterior à formação da FEB, o historiador Fernando Rodrigues demonstrou que ocorreu uma prática discriminatória na seleção para ingresso na Escola Militar:

[...] estavam sendo implantados, na Escola Militar e em outros estabelecimentos de ensino militar do Brasil, instrumentos para dificultar ou mesmo impedir a entrada, num primeiro momento, de candidatos que não se enquadrassem no novo modelo exigido para ser Oficial do Exército, ou seja, indisciplinados e/ou associados à política e, num segundo momento, de comunistas, de filhos de estrangeiros, de negros, de judeus e de muçulmanos, grupos considerados subversivos ou inferiores para a formação de uma elite militar. ${ }^{16}$

Isso explica a quase ausência de oficiais negros na FEB. Na amostra que obtivemos, atentamos nesse sentido e foi realizado um cruzamento entre as patentes

13 COSTA PINTO, L. A., 1998, p. 159 apud SILVA, op. cit., p. 41.

14 SILVA, op. cit., p. 41.

15 RODRIGUES, Leôncio Martins. Industrialização e atitudes operárias, estudo de um grupo de trabalhadores. Rio de Janeiro: Centro Edelstein de Pesquisas Sociais, 2009. p.12-14. Disponível em https://play.google.com/books/reader?id=DFMDCgAAQBAJ\&hl=pt\&pg=GBS.PP1.w.2.0.0.

16 RODRIGUES, Fernando da Silva. Indesejáveis: instituição, pensamento político e formação profissional dos oficiais do exército brasileiro. São Paulo: Paco Editorial, 2013. p. 114. 
mais altas encontradas - terceiro sargento, segundo sargento e primeiro sargento com o critério racial. Tudo indica que, mesmo entre as praças, a ascensão de negros aos postos mais importantes era exceção: dos 86 sargentos encontrados, 78 eram brancos, 6 de pele parda clara, 1 de pele parda, 1 de pele parda escura. Nenhum foi declarado de pele morena ou preta.

A amostra sugeriu que, assim como no caso da seleção para o oficialato, o critério racial também era parte estruturante da hierarquia militar das praças no Exército Brasileiro, naquele momento. Na FEB, ocorreu miscigenação racial, mas praticamente restrita às patentes mais baixas, entre os trabalhadores pobres convocados para lutar na guerra, como soldados e cabos. Mesmo nas patentes de praças graduados, como entre os sargentos, praticamente não havia negros, assim como entre os oficiais. Dessa forma, podemos dizer que assim como na sociedade civil, também havia racismo estrutural na FEB.

Outro segmento importante da hierarquia, do ponto de vista quantitativo, é o segmento da baixa oficialidade, do qual apresentamos um breve perfil. Os oficiais subalternos - primeiros tenentes, segundos tenentes e aspirantes - lidam diretamente com os praças e os conduzem nas ações táticas em campo de batalha. Esse segmento também foi muito afetado por ocasião das convocações de oficiais da Reserva (R2), oriundo da vida civil.

Os efetivos do Exército brasileiro sofreram um surto de crescimento com a mobilização. Em 1939, contava com um efetivo de 60 mil homens, ${ }^{17}$ passando para algo próximo de 95 mil homens em 1942, ${ }^{18}$ depois para 163.391, em meados de $1943,{ }^{19}$ chegando em dezembro do mesmo ano ao efetivo de 175.437 homens. ${ }^{20} \mathrm{Em}$ um curto período de tempo, após o início da mobilização e esforço de guerra, notamos que o efetivo do Exército Brasileiro ficou três vezes maior que em tempos de paz.

Para suprir a necessidade de oficiais, foram convocados, em grande escala, oficiais da Reserva que haviam cursado o Centro de Preparação de Oficiais da Reserva (CPOR). O historiador Cesar Campiani Maximiano apontou que de todos os oficiais subalternos da infantaria na FEB, 301 eram oficiais da reserva $\mathrm{R} 2$, oriundos dos CPOR, e 266 eram formados na Escola Militar do Realengo, e que, em alguns momentos da campanha, a quantidade de oficiais da reserva $\mathrm{R} 2$, na primeira linha, foi superior a $60 \%$ em algumas companhias. ${ }^{21}$

\footnotetext{
AHEx, Relatório do Ministro da Guerra de 1944, p. 84.

AHEx, op. cit., 1943, p. 146.

Ibidem.

20 AHEx, op. cit., 1944, p. 84.

21 MAXIMIANO, Cesar Campiani. Barbudos, sujos e fatigados: soldados brasileiros na Segunda Guerra Mundial. São Paulo: Grua, 2010. p. 71-72.
} 
Esses oficiais R2 eram profissionais liberais, médicos, advogados, professores, arquitetos, comerciantes, funcionários públicos, veterinários. Representavam uma classe social distinta dos convocados como praças, que também tinham experiência civil no seio das universidades, movimentos estudantis, no mundo do trabalho, representavam variadas ideologias, percepções de mundo e que precisaram se adaptar à vida militar durante sua formação no CPOR. Essa formação era muito distinta da formação da Escola Militar. Enquanto o curso da Escola Militar era cercado de cuidados, em regime de internato, por quatro anos, os cursos do CPOR eram uma alternativa de prestação do serviço militar obrigatório para os estudantes universitários de todo país. Seus alunos matriculavam-se e frequentavam o curso somente nos fins de semana, adidos a quartéis, não isolados do restante da tropa. Essa diferenciação entre os oficiais da ativa e da reserva foi fundamental para este trabalho.

Demonstramos que trabalhadores de várias profissões, do campo e da cidade, de diferentes regiões do Brasil, com variados níveis de instrução, de várias raças e até mesmo os indesejáveis - comunistas, negros, filhos de judeus, imigrantes alemães, italianos e japoneses - foram incorporados à FEB. Os esforços da década anterior para homogeneizar o Exército e distanciar a caserna da política, bem conhecidos na historiografia ${ }^{22}$, não se aplicaram à FEB. Assim como ocorreu em todos os exércitos dos países que lutaram a Segunda Guerra Mundial, a FEB tornouse uma tropa majoritariamente constituída de cidadãos trabalhadores, convocados e obrigados a cumprir seu dever, pagando o tributo de sangue para o Estado brasileiro.

Podemos dizer, também, que era uma tropa de trabalhadores temporariamente fardados e militarizados. Enquanto durasse seu serviço militar, eram, de fato, militares. Deviam ocupar um lugar na hierarquia, seguir as normas, regulamentos, ritos, aderir aos símbolos e signos militares, lutar e vencer uma guerra. Nos resta saber como essa experiência foi vivida coletivamente.

\section{Cruzando fronteiras: quando o mundo do trabalho invade a caserna}

Depois da convocação, apresentação, seleção, milhares de jovens brasileiros ingressaram no Exército e iniciaram seu contato com a vida militar, ou a reiniciaram, caso dos reservistas que haviam prestado serviço militar obrigatório nos anos imediatamente anteriores.

Tomamos dois cuidados antes de apresentar os testemunhos e narrativas memoriais. O primeiro foi reconhecer que a entrada de um indivíduo na caserna

22 Entre os historiadores que estudaram essas reformas encontram-se, entre outros, José Murilo de Carvalho, Fernando Rodrigues, Frank D. Mccann e o antropólogo Celso Castro. 
equivale a cruzar uma fronteira. A vida militar era [ainda é] rigidamente pautada nos detalhes de regulamentos, regimentos, manuais técnicos e de campo, além do Estatuto dos Militares. Por exemplo, segundo o Regulamento Disciplinar do Exército (RDE), "a disciplina é o exato cumprimento dos deveres de cada um, em todos os escalões de comando e em todos os graus da hierarquia, que confere, progressivamente, autoridade ao de maior graduação ou posto". ${ }^{23} \mathrm{~A}$ importância da hierarquia e da disciplina se destacam como fundamentos da instituição, a continência individual é vista como "prova de disciplina, que o militar é obrigado a prestar aos superiores". ${ }^{24}$

Nesse sentido, convém trazer a tona alguns elementos já abordados pelos antropólogos brasileiros que estudam a vida militar. Para Piero Leirner, ser militar significa ocupar um lugar na hierarquia, estar imerso numa rede de relações com regras próprias, sujeito a normas diferenciadas em relação aos civis. A hierarquia é a distinção máxima, pois determina quem é de dentro e quem é de fora. A hierarquia é um fato social total que, ao mesmo tempo, é um princípio formador de uma identidade coletiva e sua fronteira com o mundo de fora. ${ }^{25}$

Celso Castro afirma que tornar-se militar significa, acima de tudo, deixar de ser civil. A oposição entre civis e militares é estruturante da identidade militar. Torna-se necessário, para adquirir essa nova identidade, passar por um processo de desconstrução da sua identidade anterior. Para ele, mundo/meio militar e mundo/meio civil são categorias nativas, estruturantes da visão de mundo militar e não somente termos descritivos. ${ }^{26}$

Para Lauriani Porto Albertini, no que se refere à identidade militar, "o componente fundamental de sua visão de mundo é uma clara distinção entre as características atribuídas ao 'mundo militar', o ‘aqui dentro', e as atribuídas ao ‘mundo civil', o 'lá fora"'. ${ }^{27}$

Entre toda essa transformação, essa desconstrução de identidades dos indivíduos como cidadãos, trabalhadores, civis, e a construção da nova identidade, com base nos valores militares, está um período de intenso treinamento e adaptação. Há um detalhe importante. Eles foram convocados para a FEB e não para servir nas demais unidades do EB.

\footnotetext{
23 AHEx, Acervo de Manuais e Regulamentos, Regulamento Disciplinar do Exército de 1942. p. 3.

24 AHEx, Acervo de Manuais e Regulamentos, Regulamento de Continências, Honras e Sinaes de Respeito das Forças Armadas de 1942. p. 4.

25 CASTRO, Celso; LEIRNER, Piero. (org.) Antropologia dos militares: reflexões sobre pesquisas de campo. Rio de Janeiro: Ed. FGV, 2009. p. 81.

26 Ibidem, p. 24.

27 Ibidem, p. 81.
} 
Quando observamos atentamente os relatórios do Ministro da Guerra, general Dutra, percebemos que a primeira diferença entre a FEB e o restante do Exército Brasileiro residia em questões de estrutura militar: a FEB tinha diferente doutrina de emprego, novos meios materiais, armamentos e técnicas, diferença na quantidade de efetivo e mesmo um novo estilo de comando, segundo os manuais de campanha do exército estadunidense adotados na FEB. Somou-se a isso o emprego extraterritorial da FEB, que treinou no Brasil e atravessou o Atlântico para lutar na Itália. Nesse sentido, a FEB era estruturalmente diferente do EB. Acreditamos que essa diferenciação potencializou experiências que podem ter forjado uma identidade coletiva distinta dos militares do EB.

Outro ponto que merece cuidado é a questão do crescimento observado em todos os exércitos que lutaram na Segunda Guerra Mundial. Como já vimos, o Exército Brasileiro quase triplicou seu tamanho durante a guerra. O historiador Cesar C. Maximiano afirmou que as organizações militares "deixaram de ser, ao menos no decorrer do conflito, forças formadas exclusivamente por profissionais e passarama consistir em corporações cuja proporção de civis convocados era avassaladora em relação aos militares de carreira". ${ }^{28}$

O historiador Francisco C. A. Ferraz identificou a FEB como sendo a primeira, e única vez, na história brasileira, em que uma força armada composta de "cidadãos soldados brasileiros" foi lutar contra cidadãos soldados de outra nação, em outro continente. Por cidadãos soldados o autor entende que são indivíduos que, ao prestar o serviço militar temporário, adquirem a qualificação de sua cidadania por meio do pagamento do tributo de sangue. ${ }^{29}$

Considerando as mudanças, Cesar Campiani Maximiano ressaltou que os "exércitos que os expedicionários conheceram na Itália, eram como a FEB, consequência da condição de nações em armas. Britânicos e Americanos viviam sob ferrenhas disciplinas em suas casernas de tempo de paz". ${ }^{30} \mathrm{O}$ historiador argumentou que, em tempo de paz, muitos soldados brancos sentiam a vida militar separada por castas hierárquicas, a mesma segregação que os negros sofriam na sociedade. Maximiano afirmou que a rigidez disciplinar foi amenizada por necessidade, pois o enorme afluxo de civis convocados que adentrou o Exército não aceitou as mesmas condições de severidade e servilismo dos quartéis. ${ }^{31}$ O US Army

\footnotetext{
MAXIMIANO, op. cit., p. 361.

29 FERRAZ, Francisco CÉSAR Alves. A guerra que não acabou: a reintegração social dos veteranos da Força Expedicionária Brasileira (1945-2000). Londrina: Eduel, 2012. p. 45.

30 MAXIMIANO, op. cit., p. 368.

31 Ibidem.
} 
saltou de um contingente de 16.624 oficiais e 249.441 praças, para mais de 772.863 oficiais e 7.305 .854 praças. ${ }^{32}$ Praticamente 30 vezes maior.

O historiador inglês Geoffrey Field analisou as transformações ocorridas no Exército inglês a partir do início da Segunda Guerra Mundial, em 1939, constatando um salto de 200 mil homens para aproximadamente 3 milhões e 800 mil o que o transformou rapidamente de uma pequena força profissional em uma força de conscritos mais de dez vezes maior. ${ }^{33}$ Field adotou uma perspectiva de reconhecer os convocados como trabalhadores e, a partir disso, identificar quais as atitudes coletivas eles tomaram para lutar contra a severidade do sistema militar inglês e modificá-lo.

Field fez uma história social dessa transformação do Exército inglês e observou que a grande expansão de contingentes fez com que soldados treinassem sem armas, fossem forçados a dormir em condições miseráveis em barracas, que seus conhecimentos civis não foram aproveitados nas funções militares a eles destinadas. ${ }^{34} \mathrm{~A}$ maioria dos convocados constatou que o período básico de treinamento (educação física, ordem unida, marchas, saudações) só servia para conformar a obediência aos superiores. Rapidamente, os soldados aprenderam que a caserna era um mundo dividido entre nós e eles, calculado para promover cooperação entre os soldados e obediência aos oficiais. ${ }^{35}$

Após os fracassos iniciais dos ingleses contra os alemães na França, Grécia e Creta, o comando do Exército, pressionado por uma população que via o excesso de rigor disciplinar como um traço de um Exército obsoleto, decidiu implementar reformas para elevar o moral da tropa. Mas isso não aconteceu sem a luta dos soldados civis de uniforme. Muitos deles ex-operários, comerciantes ou trabalhadores da Trade Union, não aceitaram a rigorosa diferenciação de tratamento entre soldados e oficiais, muito menos as regalias dos últimos. Várias vezes, os soldados ingleses, junto com marinheiros e tripulações da força aérea, realizaram greves, recusaram-se a lutar ou embarcar em navios precários, levantando-se contra maus tratos, falta de condições básicas de higiene e supressão básica de direitos. Os soldados que entenderam estar lutando pela democracia, sentiram-se à vontade

\footnotetext{
Ibidem, p. 361.

33 FIELD, Geoffrey. Civilians in uniform: Class and politics in the British Armed Forces, 1939 - 1945. International Labor and Working-Class History, n80, fall 2011. p. 121-147.

34 Ibidem, p. 122.

35 FIELD, op. cit., p. 123.
} 
para lutar abertamente por seus direitos e melhores condições, mesmo ameaçados com a pena de morte, no caso de motins. ${ }^{36}$

Para compreender a identidade coletiva que surgiu na FEB foi necessário cruzar esses dois campos de pesquisa, esses dois olhares, da antropologia dos militares e da história social. O olhar antropológico foi capaz de lançar luz sobre a forma de pensar e agir do comando da FEB, enquanto o olhar da história social trabalho pôde esclarecer as ações e a consciência dos soldados cidadãos, dos civis convocados, dos trabalhadores de farda. Acreditamos que a Segunda Guerra Mundial, com a elevação dos contingentes e a massa de conscritos incorporada aos exércitos, parece ter instalado um momento de exceção referente à separação entre mundo civil e mundo militar. Algo mais, a guerra acabou reunindo trabalhadores de diferentes cantos do globo e esses homens trocaram experiências.

A possibilidade de troca de experiências no teatro de operações italiano era real. A Itália havia se tornado um verdadeiro mosaico cultural. Nele estavam presentes os civis italianos, os combatentes partiggiani, guerrilheiros da resistência - muitos comunistas - contra os alemães e italianos fascistas. As tropas aliadas compreendiam elementos franceses (Força Expedicionária Francesa, organizada

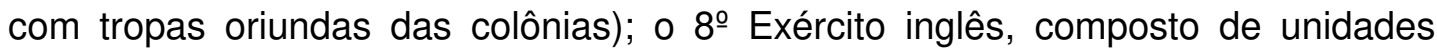
inglesas que anteriormente lutaram no norte da África, além de australianos, indianos, neozelandeses, sul-africanos e escoceses; o $\mathrm{V}$ Exército americano, composto por unidades militares normais e unidades de segregação racial, como a 92 $2^{\text {a }}$ Divisão de Infantaria colored e uma divisão de nipo-americanos (nessas unidades todos os oficiais eram brancos).

\section{A consciência febiana}

Acessar o passado vivido através dos testemunhos demandou cuidado porque a memória, assim como qualquer fonte, foi submetida aqui à crítica metodológica. Nesse sentido, o historiador Fernando Cartroga ressaltou que "a memória e o esquecimento se exigem reciprocamente", e que seja "como recordação ou como esquecimento, nunca é o passado que se impõe ao presente, mas é este, enquanto permanente tensão e protensão que vai urdindo as tonalidades [...] de presença do ausente". ${ }^{37} \mathrm{E}$ que $\mathrm{o}$ historiador não pode ignorar a "dialética que existe entre 0 recordado e o esquecido". 38

36 Ibidem, p. 130-132.

37 CARTROGA, Fernando. Memória, história e historiografia. Rio de Janeiro: Ed. FGV, 2015. p. 16.

38 Ibidem, p. 52. 
No que se refere à memória dos veteranos da FEB, destacamos que existe uma "estreita relação entre memória, identificação, filiação e distinção", ${ }^{39}$ e que a "tarefa última das liturgias de recordação é gerar coerência e perpetuar o sentimento de pertença", uma vez que "o imaginário da memória liga os indivíduos, não só verticalmente, isto é, a grupos ou entidades, mas também horizontalmente a uma vivência encadeada no tempo (subjetivo e social)".40

Muitos dos testemunhos aqui trabalhados são do livro Depoimento de oficiais da reserva sobre a FEB, publicado em 1949. Compreende uma coletânea de 20 artigos escritos por 12 oficiais subalternos da reserva, em tom analítico e severamente crítico. Registramos que, embora esse grupo não represente diretamente as vozes das praças, sargentos, cabos e soldados, suas narrativas organizadas na coletânea apresentaram muitos pontos de contato com inúmeros livros e testemunhos de pracinhas que registraram suas memórias isoladamente. Não existe um tipo de testemunho padrão devido à infinidade de experiências.

Os oficiais da reserva - R2, ${ }^{41}$ na introdução, demonstram com clareza seu objetivo: "um livro como este, nascido da luta, do sofrimento, da decepção e que não se destinou aos elogios fáceis [...], já que outros mais cultos que nós não tiveram oportunidade ou não quiseram falar, era preciso, portanto, que nós viéssemos contar nossas impressões[...]". ${ }^{42}$ E ainda:

O silêncio fácil e sem riscos, a conspiração do silêncio que ninguém ousa quebrar, pode tornar-se criminosa, quando se cala sobre os erros cometidos, quando não se ousa expor as deficiências observadas. Criminosa, não somente porque se estará, assim, preparando o caminho da repetição destes erros, de nada valendo o sacrifício daqueles que, por causa deles, sofreram uma vez [...] O silêncio relativo a tudo o que se passou, vem, também, criar em torno das autoridades e das suas afirmações, unilateralmente apologéticas, uma atmosfera de falsa confiança, de farisaísmo consciente, de convencional verniz oficial que soa falso e que ninguém leva a sério. ${ }^{43}$

Portanto, o livro se anunciou como um contraponto aos silêncios da memória oficial em suas comemorações ou em sua principal narrativa. Intitulado A FEB pelo seu comandante, foi editado pelo general João Baptista Mascarenhas de Moraes, que havia sido o Comandante em Chefe da FEB. A obra foi lançada um ano depois do regresso da FEB, em 1946. 
Enquanto o comando do Exército categorizava suas diferentes unidades militares em tipo normal e tipo FEB num período de anomalia, o expedicionário, tenente da reserva José Goes Xavier de Andrade, resolveu utilizar outras categorias para explicar essa divisão. Para ele, passaram a existir o Exército de Caxias e o Exército da FEB. O termo Exército de Caxias era comumente usado na época, tinha respaldo institucional porque se referia ao patrono do Exército, o Duque de Caxias. A novidade ficou por conta do termo Exército da FEB.

Logo que o tenente José Goes Xavier de Andrade chegou à Itália, percebeu que "os soldados dividiam em dois o Exército Nacional: referiam-se à FEB como um 'novo Exército', bem diferente daquele outro Exército que ficara no Brasil, e que eles sempre ouviram chamar de 'Exército de Caxias'". ${ }^{44}$ E essa divisão era mencionada "toda vez que os expedicionários estabeleciam comparação entre os métodos, costumes e princípios adotados no Brasil e os vigentes nos campos de operações na Itália". 45 Mas nos interessa, ao refletir sobre Caxias, o que o tenente R2 Andrade explicou acerca do seu ponto de vista:

\begin{abstract}
Adiantaremos que o Duque de Caxias, Patrono do Exército, não era bem interpretado e compreendido pelo soldado. Por quê? Uma exaltação sem método psicológico, fê-lo um símbolo inatingível. Os símbolos, embora alçados às alturas da glória, não devem perder a natureza humana que se identifica com aqueles a quem servem de paradigma. [...] Em todos os quartéis brasileiros, Caxias foi apresentado com um exagero tal que o homem comum não pode compreender. Para o soldado simples, cheio de fraquezas e falibilidades humanas, os traços da vida realmente predestinada do Duque de Caxias, aquela perfectibilidade realçada numa exaltação quase mística, tornouse inimitável, inalcançável como símbolo. Surgiu o oposto do que se desejava obter: Caxias era uma coisa impossível... Qual foi então o resultado? Todos nós o sabemos: para o soldado, "Caxias" é o oficial, o sargento, o praça exagerado, rigoroso em demasia. É o militar que vive com o dedo nos artigos do Regulamento, sem a tolerância da eqüidade. É o soldado "puxasaco", quando devia ser o contrário. ${ }^{46}$
\end{abstract}

Nessa questão das lembranças e esquecimentos, da seletividade da memória que atua como barreira de pertencimento às identidades e grupos, essa informação é extremamente relevante. Caxias, no panteão de heróis do Exército brasileiro, foi feito um homem monumento. A memória oficial do exército o alçou a esta posição, dele foi [e ainda é] o Dia do Soldado, dele foram tiradas as qualidades desejáveis aos cadetes, a ele foram devotadas práticas comemorativas. Notamos que os expedicionários da FEB apelaram para o modelo oficial, transformaram-no em modelo do que não se deve ser, trouxeram o sentido cotidiano, informal, corriqueiro, do que era ser um caxias, na linguagem da caserna.

44 Ibidem, p. 311.

45 Ibidem.

46 ARRUDA, op. cit., p. 311-312. 
A partir da lógica exposta pelo tenente da reserva, frisamos que as diferenças percebidas entre o Exército de Caxias e o Exército da FEB eram derivadas das experiências vividas pelos soldados. Os civis convocados para a FEB vivenciaram as duas realidades, o período de treinamento no Brasil e, posteriormente, o embarque e a luta com a FEB na Itália.

Desde a viagem no navio de transporte estadunidense, os brasileiros se impressionaram com a eficiência da organização do modelo estadunidense. $O$ tenente R2 José Alfio Piason apontou que "dói-nos também, dizer ter havido centenas de vezes mais higiene em nosso acampamento, acantonamentos, e nas próprias linhas de frente da Itália do que em qualquer quartel onde estivemos no Brasil". ${ }^{47}$ A justificativa para ele era clara:

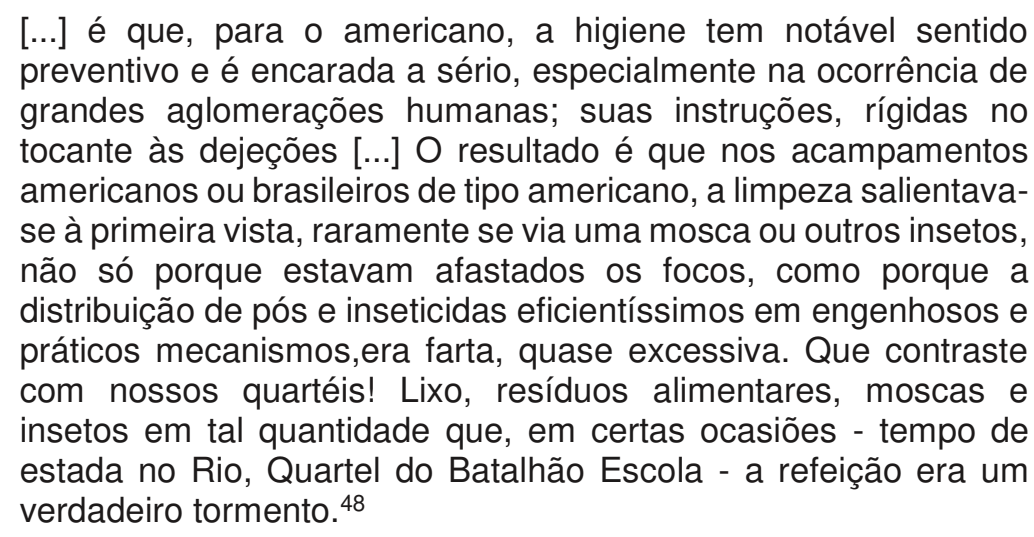

O tenente R2 Andrade assinalou que as tropas americanas conheciam bem os manuais, respeitavam os ensinamentos ali contidos, a disciplina "deve estar em tudo que o cerca [...] era como se cada um fosse o comandante de si mesmo. E os brasileiros se adaptaram àquele estado geral como peças de máquina". ${ }^{49}$ No modelo americano, a vigilância não é sobre os homens, mas sobre as tarefas e, portanto, a ordem, a obrigação, vira rotina.

Além do impacto da doutrina estadunidense, a guerra possibilitou a troca de experiências entre essas pessoas nascidas em locais tão distantes: tornou-se inevitável aos brasileiros realizar comparações entre o Exército brasileiro e os demais exércitos aliados.

O tenente R2 José Goes Xavier de Andrade percebeu que "o soldado brasileiro foi encontrar a novidade da alimentação comum a oficiais e praças, na FEB, ou melhor, com os americanos do norte". ${ }^{50}$ Percebeu também que, no Brasil, os praças nutriam forte antipatia com o "rigor disciplinar que os divorciava dos oficiais. [...] à

\footnotetext{
47 Ibidem, p. 93.

48 Ibidem.

49 ARRUDA, op. cit., p. 359

50 Ibidem, p. 325.
} 
maneira de falar, à rigidez das atitudes e principalmente à continência em toda parte, a cada canto, a todo momento, mesmo na rua. A obrigação de ceder o lugar no bonde, no ônibus, no cinema, o que constrange [...]". ${ }^{51}$ Para ele, muitas vezes, o praça se humilhava ainda mais, fingindo que não via o superior hierárquico, fingindo observar uma vitrine. ${ }^{52}$

O sargento Boris Schnaiderman, também convocado, observou a diferença e relatou que "é impossível deixar de reconhecer: há muito mais bom humor e simplicidade no Exército americano do que no nosso [...] a disciplina parece basearse mais na execução das tarefas do que na prestação de continência, os oficiais não vivem gritando com as praças". ${ }^{53} \mathrm{O}$ soldado Geraldo de Figueiredo teve uma impressão consideravelmente semelhante e recordou que "aqui havia aquela caxiagem, aquela crença terrível, aquela exigência, era um exército quase nazista, sabe? [...] E lá nós encontramos o americano [...] já tinha outra tática, outra política pra tratar com os soldados. Então o soldado era tratado com mais dignidade". ${ }^{54}$

$\mathrm{Na} F E B$, quando se deu a aproximação entre oficiais e praças, ocorreu com inspiração nos exércitos americanos e ingleses, ou por conta da vida na linha de frente, nos duros combates. O tenente da reserva Massaki Udihara recordou, em seu diário, que numa noite de novembro de 1944 uma patrulha foi pega de surpresa e que ele, como observador distante, notou que "enquanto tudo se mantinha no efeito pirotécnico era ainda suportável. Mas quando se vê o efeito na integridade do homem, as lacerações ocasionadas pelas armas de destruição consciente e brutal, sente-se um choque e fica-se com um horror". ${ }^{55}$

O tenente Udihara demonstrou, em seu íntimo, a grande sensação que a vida na linha de frente imprimiu nos seus dias: "Sensação de morte bem próxima: "medo como nunca senti". Pelo que vejo, prezo demais a vida. Impressão de que não escaparia dessa. Não há dúvida de que sou mais medroso do que penso". ${ }^{56} \mathrm{Em}$ outra página, registrou com grande preocupação: "um ambiente de receio e medo o dia todo. Uma sensação desagradável que nessas ocasiões localiza-se no epigástrio. [...] Um nervosismo de que todos parecem possuídos. [...] começam a ver em tudo influência ou ação inimiga". ${ }^{57}$

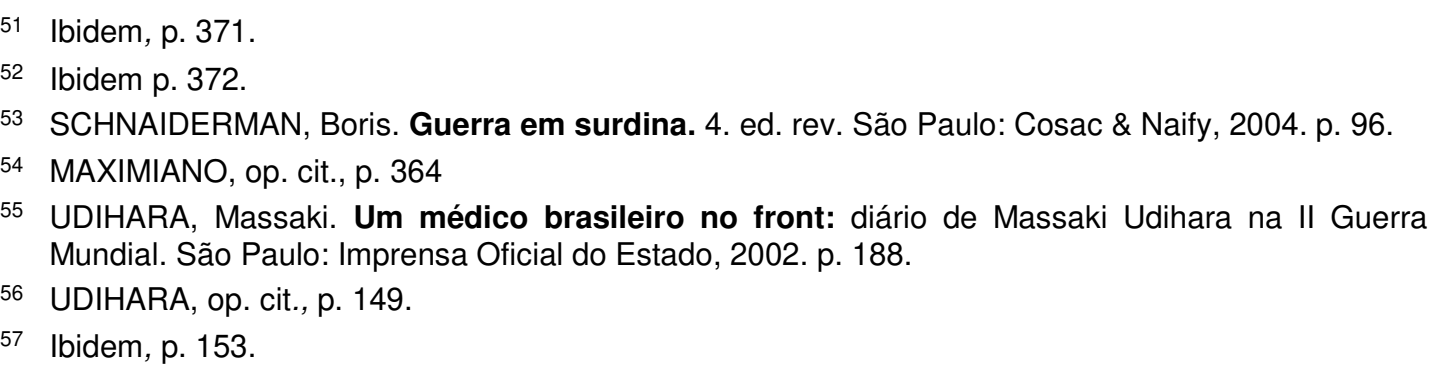


A convivência prolongada na violência da linha de frente era uma experiência que atuava como um rolo compressor, a guerra compactava o indivíduo e as coletividades, configurando-Ihes até mesmo uma aparência típica. Ao referir-se aos homens que estavam nos fox holes nas posições mais avançadas, o tenente Udihara, sensivelmente, registrou em seu diário que "quem vê a fisionomia dos que estão nessa condição pode bem avaliar o estado em que se encontram e como estão se sentindo. Faces abatidas, encovadas, com todas as saliências mais visíveis e um brilho mortiço nos olhos, de animal há muito tempo acuado". ${ }^{58}$

O tenente R2 Tulio Campelo de Souza recordou-se que, com o passar do tempo, as preocupações das praças que comandava na infantaria "eram as seguintes, por ordem de importância, sobreviver, ter o que comer, encontrar um lugar seguro e seco onde dormir". ${ }^{59} \mathrm{O}$ tenente R2 Goes de Andrade testemunhou que "é realmente duro [...] passar dias e meses dentro do mato, comendo em marmitas [...] mãos sujas ou as lavando muito mal no capacete de aço [...] sentimos quanto valem objetos de que nos utilizávamos sem dar importância". ${ }^{60}$

Os homens da linha de frente desenvolveram uma outra visão da hierarquia e disciplina. O tenente da reserva Goes de Andrade argumentou que "aquele rigor do quartel deixou de ser necessário, em plena campanha a disciplina afrouxou as rédeas. Certas exigências - necessárias no quartel - perderam a razão de ser". O perigo da morte no combate fez desaparecer "no comandante o professor e no soldado, acabou-se o aluno". ${ }^{61} \mathrm{E}$ "na guerra, porém, o perigo real é um disciplinador que está presente e vigilante. [...] o tenente e o sargento, neste ponto, sentem um grande alívio. E os soldados mais autonomia". 62

O sargento Boris Schnaiderman recordou que preferiam "a vida na linha de combate, com os seus perigos, mas também com seu quê de apaisanamento". ${ }^{63} \mathrm{Na}$ linha de frente, o tenente da reserva Goes de Andrade afirmou que

$$
\begin{aligned}
& \text { o pelotão, a companhia, vive como família. [...] Aquela vida comum } \\
& \text { vinculada pela ansiedade, sobrepôs-se às emoções humanas, às } \\
& \text { posições sociais, aos postos hierárquicos e proporcionou ao soldado } \\
& \text { brasileiro as balizas de uma grande diferenciação entre a vida militar } \\
& \text { na paz e na guerra, entre quartel e a campanha, fazendo-os distinguir } \\
& \text { o Exército Nacional, o Exército de Caxias, da FEB. }{ }^{64}
\end{aligned}
$$

\footnotetext{
58 Ibidem, p. 180.

59 ARRUDA, op. cit., p. 206.

Ibidem, p. 376.

1 Ibidem, p. 365.

22 Ibidem, p. 369.

3 SCHNAIDERMAN, op. cit., p. 104.

64 ARRUDA, op. cit., p. 371.
} 
Aquele tipo de vida, imerso de violência, medo, angústia, ansiedade crônica e privações, produzia um estreitamento de laços nunca experimentado na vida dos quartéis brasileiros. O tenente da reserva Túlio resumiu bem a vida no front: "a vida de um pelotão de fuzileiros assume aspectos estranhos e talvez contrários aos regulamentos disciplinares", ${ }^{65}$ e ainda:

\begin{abstract}
Nas conversas, durante períodos de inatividade, oficial e soldados expunham suas ideias e sentimentos como quaisquer seres humanos, paisanos, sem censura ou restrição. Também participei das queixas dos soldados [...] também critiquei e 'meti o pau' (desculpem o calão) nos responsáveis mais altamente colocados na hierarquia da FEB, sem esquecer mesmo o General Willis Crittenberg, comandante do IV Corpo do V Exército. Não há dúvida, praticávamos a democracia. ${ }^{66}$
\end{abstract}

Os testemunhos trouxeram a experiência vivida coletivamente, a qual aos poucos forjou valores de uma consciência coletiva. Inegavelmente, a linha de frente aproximou as pessoas, transformou a disciplina em algo mais espontâneo, praticamente livre dos regulamentos e coerções da caserna. Há algo de moral na disciplina da linha de frente, mais horizontalizada pelas vivências comuns, privações, medo, perdas e sofrimentos compartilhados. Também ficou claro que as ideias e experiências de cidadãos soldados de outras nacionalidades influenciaram o modo de agir dos brasileiros.

Outra constatação de grande importância para aqueles externos à caserna, portanto, que não pertenciam ao Exército profissional, foi que o sistema de valores da linha de frente, na FEB, era preferível aos valores militares do Exército de Caxias. Para esses homens, de agora em diante chamados de febianos, a disciplina envolvia também a questão da manutenção de um conjunto mínimo, básico, de conforto e humanidade para com os que estavam na linha de frente, fazendo o trabalho duro, aqueles que tudo suportavam enquanto lutavam com o inimigo. Eram percepções do cotidiano dos trabalhadores na guerra, de pessoas que reivindicavam somente condições dignas. O regulamento e a hierarquia não bastavam; os códigos que regiam a vida interna do mundo militar não constituíam um limite ou uma barreira para esses homens.

Mas o comando e grande parte dos militares profissionais continuaram seguindo a lógica do chamado Exército de Caxias. Segundo o relatório de campanha do general Zenóbio da Costa, comandante da Infantaria na FEB, o Serviço de Polícia influía diretamente no aspecto disciplinar, pois, entre suas atribuições estavam

65 Ibidem, p. 218.

66 Ibidem, p. 220 (grifo nosso). 
"executar quaisquer medidas ou ordens baixadas pelo comandante e que digam respeito a disciplina". ${ }^{67}$ Sendo o responsável também por realizar prisões, manter a ordem, quando necessário.

A disciplina era uma preocupação legítima do comando, o problema era quando ocorria a falta do Serviço de Polícia em determinadas situações. Nesses casos, os vários escalões de comando lidaram de alguma forma com os problemas ocorridos. O tenente da reserva Massaki Udihara recordou que, após uma briga com italianos, três soldados mereciam correção disciplinar. O problema foi o tipo de castigo aplicado: o subcomandante do regimento decidiu "mandar buscar dois homens fortes, amarrá-los em uma árvore e deixá-los toda noite lá, tomando chuva". ${ }^{68}$ Este castigo não estava previsto em nenhum regulamento disciplinar, nem é necessária muita imaginação para associar essa árvore a um pelourinho. Muitos testemunhos apontaram situações desse tipo de abuso, reforçando a linha de raciocínio do tenente $\mathrm{R} 2$ Goes de Andrade, que afirmou:

No quartel, ontem como hoje, defronta-se a nação, tal qual ela é, com os seus vícios, suas virtudes, sua pobreza e seus costumes. E como um reflexo da vida civil, a disciplina nas casernas trazia a marca da disciplina coletiva. O poder do superior hierárquico, semelhante ao poder do senhor de terras. O elemento disciplinador dominante era o medo, o receio do castigo, o estabelecimento de um modus vivendi desigual para uns e para outros; e condição de senhor e de subordinado com as suas regalias e desvantagens. ${ }^{69}$

O tenente Massaki Udihara, em seu diário no dia 10 de março de 1945, deixou um registro que resumiu como ficou a situação entre militares profissionais e febianos:

Depois do almoço estive com o Mendes e o Piason. [...] Temos uma opinião que é unânime sobre a capacidade e a proficiência dessa gente. Na parte que nos toca, terão em nós os maiores inimigos desse sistema e [...] terão que falar com dados e observação, sobre tudo que aconteceu aqui. 0 repositório de fatos que se está acumulando é suficiente para se falar a vida toda. Em meio a essa gente não merece nada pelo seu caráter e moral. Uma verdadeira cálifa de incompetentes e desonestos. ${ }^{70}$

$\mathrm{Na}$ FEB, os órgãos de retaguarda, como o Depósito de Pessoal, a rotina de caserna foi restabelecida fazendo reaparecer o Exército de Caxias. O historiador Maximiano relatou um caso em que dois soldados se rebelaram contra a

\footnotetext{
67 AHEx, acervo FEB, Relatório de Campanha do Comandante da Infantaria Expedicionária, p. 60.

68 UDIHARA, op. cit., p. 100.

69 ARRUDA, op. cit., p. 315.

70 UDIHARA, op. cit., p. 293 (grifo nosso).
} 
intransigência que imperava naquela unidade, sendo julgados e condenados. ${ }^{71}$ Segundo sua sentença, os soldados estavam embriagados quando receberam ordem de se dirigir ao xadrez, ao que responderam:

Não vou, não há quem me leve, e eu vou the quebrar todo, vou ajustar contas com você, seu caxias filho da puta. Esta é a oportunidade que tenho para me vingar deste caxias filho da puta, que só quer saber de dar instrução e traquejar. Eu mato. Há muito que eu desejo tirar uma desforra dessa caxiagem. ${ }^{72}$

Não resta dúvida de que durante a campanha já existia diferenciação entre nós e eles. Os febianos criaram uma nova consciência coletiva a partir das experiências que vivenciaram. Essa consciência estava impressa na sua identidade coletiva, que reverenciava valores distintos dos militares profissionais, que agia com base em diferentes perspectivas e interesses, que via na FEB um modelo alternativo ao Exército de Caxias.

Defendemos que a construção de identidades distintas, ambas baseadas em experiências vividas em momentos distintos, sendo uma identidade nova, a dos febianos, e uma antiga, a dos militares profissionais, produziram consciências coletivas antagônicas. Nesse sentido, recorro às assertivas do historiador Edward Palmer Thompson:

Por classe, entendo um fenômeno histórico [...] como algo que ocorre efetivamente (e cuja ocorrência pode ser demonstrada) nas relações humanas. [...] Ademais, a noção de classe traz consigo a noção de relação histórica. [...] A relação precisa estar sempre encarnada em pessoas e contextos reais. Além disso, não podemos ter duas classes distintas, cada qual com um ser independente, colocando-as a seguir em relação recíproca. Não podemos ter amor sem amantes, nem submissão sem senhores rurais e camponeses. A classe acontece quando alguns homens, como resultado de experiências comuns (herdadas ou partilhadas), sentem e articulam a identidade de seus interesses entre si, e contra outros homens cujos interesses diferem (e geralmente se opõem) dos seus. A experiência de classe é determinada, em grande medida, pelas relações de produção em que os homens nasceram - ou entraram involuntariamente - A consciência de classe é a forma como essas experiências são tratadas em termos culturais: encarnadas em tradições, sistemas de valores, ideias e formas institucionais. Se a experiência aparece determinada, o mesmo não ocorre com a consciência de classe. Podemos ver uma lógica nas reações de grupos profissionais semelhantes que vivem experiências parecidas, mas não podemos predicar nenhuma lei. $A$ consciência de classe surge da mesma forma em tempos e lugares diferentes, mas nunca exatamente da mesma forma. ${ }^{73}$

71 MAXIMIANO, op. cit., p. 375.

72 Ibidem, p. 375.

73 THOMPSON, E. P. A formação da classe operária inglesa. v. I, A árvore da liberdade. Rio de Janeiro: Paz e Terra. 1987a. v. 1 - A árvore da liberdade, p. 9-10. (grifo nosso). 


\title{
Em rota de colisão: tentativas de agência dos febianos
}

Eram comuns as arbitrariedades cometidas por militares profissionais. $O$ tenente da reserva José Alfio Piason revelou que às vésperas do embarque, o general Zenóbio da Costa decidiu que nenhum soldado brasileiro podia ter bigode e ordenou que todos que o usassem, deveriam raspá-lo. Segundo o tenente Piason,

A respeito dos bigodes pode-se dizer o seguinte: sabida a atração que o brasileiro atual tem pelo bigode, melhor seria não ligar maior atenção a isso do que tentar aboli-lo; no entanto, certo General, segundo parece, sabedor de não ter o americano por ele, bigode, igual simpatia, tentou fazer que todos os elementos da FEB abandonassem seu uso; todavia, ao invés de convencer, ordenou; e foi então que a oposição se revelou em toda sua intensidade; não havendo regulamento a proibir seu uso, tornou-se possível desobedecer sem ser punido; [...] Foi esse, talvez, um dos primeiros e importantes gérmens de rebeldia, que, logicamente, em certas ocasiões teria de se agravar [...] como revide, mais aumentou a resistência dos pequenos, pois alguns sem bigodes... passaram a tê-lo. ${ }^{74}$

Nosso interesse, no caso da revolta dos bigodes, recai sobre a importância dos regulamentos para os militares profissionais e para os febianos. Nesse sentido, o historiador E. P. Thompson afirmou que

\begin{abstract}
as regras e categorias jurídicas penetram em todos os níveis da sociedade, efetuam definições verticais e horizontais dos direitos e status dos homens e contribuem para a auto definição ou senso de identidade dos homens. Como tal, a lei não foi apenas imposta de cima sobre os homens: tem sido um meio onde outros conflitos sociais tem se travado. ${ }^{75}$
\end{abstract}

As relações de poder entre os militares profissionais e os febianos também perpassavam a questão dos ordenamentos jurídicos, nesse caso, os regulamentos, especialmente no que se refere aos homens que estavam amarrados a esses ordenamentos e que conseguiam manejá-los para se reapropriar deles, quando viam oportunidade de conquistar vantagens disso coletivamente. E é sob esse aspecto que a revolta dos bigodes deve ser encarada.

Para os militares profissionais, com sua visão estritamente regulamentar, hierárquica, acerca da disciplina, esses atos constituíam mera indisciplina ou rebeldia. Mas para os febianos, que tinham uma identidade coletiva em formação, baseada em novas experiências e no enfrentamento à caxiagem dos militares profissionais, esses episódios revelam que eles tinham consciência das relações de

\footnotetext{
74 ARRUDA, op. cit., p. 97.

75 THOMPSON, E. P. Senhores e caçadores: a origem da lei negra. Rio de Janeiro: Paz e Terra, 1987. p. 358.
} 
poder, mas encaravam os regulamentos sob uma perspectiva de direitos, impondo um limite para a severidade militar.

Outro ponto a destacar é a questão do uniforme tipo FEB adotado pelos pracinhas. Além da baixa qualidade, o tenente R2 Mario Amaral recordou que "os uniformes da FEB foram confeccionados quer no formato, quer na cor, com extrema semelhança dos uniformes usados pelos alemães". ${ }^{76}$

Com o rigoroso inverno italiano, ocorreu utilização de peças do exército estadunidense, fornecidas em grande número para os pracinhas. A customização do uniforme com peças de outros exércitos e de civis italianos foi comum, resultando numa despadronização em larga escala, descumprimento do plano de uniformes da FEB, por necessidade ou modismo.

O comando, respondeu com caxiagem à iniciativa dos soldados, como consta numa recomendação sobre uniformes em boletim:

I - Algumas praças estão andando com blusa feita com o cobertor de lã e, hoje mesmo, este Comando teve o desprazer de punir dois soldados do $11^{\circ} \mathrm{Rl}$, que assim se fardaram. É uma grave alteração do uniforme e, ao mesmo tempo a ostentação de haverem inutilizado um artigo da Fazenda Nacional. [...] Este comando lamenta em ser levado a declarar que responsabilizará também os oficiais cujos comandados venham a contrariar essas recomendações. ${ }^{77}$

Durante a campanha, surgiram pequenos jornais de trincheira, feitos por homens da linha de frente para homens da linha de frente. Sua concepção, nesse sentido, era carregada com os valores vindos da experiência de combate e de privações. Na FEB, rapidamente surgiu um desses jornais, chamando $E$ a Cobra fumou! Em se tratando da questão do uniforme, nos interessa a posição do Cobra:

[...] tendência do pracinha em copiar uniformes de outros exércitos, faz o resto. $O$ resultado é que em cada 5 soldados, cada um se veste de maneira diferente. Até peças do fardamento americano chegam a vestir. Nos meses frios, o uso geral das roupas de lã, capote e galochas não tornou o problema tão grave. [...] Ao nosso ver, a maior dificuldade reside nesse fato. $A<$ farda tedesca $>$ é repelida por gregos e troianos. E, sejamos francos, ela deixa muito a desejar: fazenda imprópria, apertada, desajustada e por isso mesmo deselegante, forma um contraste aos esportivos e práticos uniformes americanos e ingleses. Alguns espíritos inovadores tem posto em uso uma combinação que bem poderia ser aprovada pelos superiores: camisa de tricoline, de graduado (sem as insígnias, é claro...) e gravata, calça escura de brim, sem perneiras e gorro sem pala de lã. Em dias mais frios, acrescentar o uso da jaqueta impermeável. Vale apena experimentar? ${ }^{78}$

76 ARRUDA, op. cit., p. 173-174.

77 AHEx, ACERVO FEB, Caixeta Serviço Especial FEB, Boletins internos da pagadoria fixa 1응 Semestre de 1945, Boletim interno no 12, 16/03/1945.

78 E a Cobra Fumou!, n.8, p. 4. 
A constatação de que o uniforme era similar ao alemão, feio em comparação aos demais uniformes aliados, de baixa qualidade, resultou numa sugestão para uso de peças de uniforme fora do padrão definido no plano de uniformes tipo FEB. A iniciativa foi sintetizada na última frase: Vale a pena experimentar? Essa frase demonstrou a utilização do jornal como veículo de agência, na tentativa de uma organização radicalmente contrária à hierarquia militar, uma organização de baixo para cima, na esperança de uma aceitação em larga escala por parte dos pracinhas e, a partir daí, conformismo dos escalões superiores.

As reivindicações por algum conforto que amenizasse o sofrimento da linha de frente eram comuns no jornal, personificadas na coluna do Neurastênico, que não perdoou o rancho: "A turma reclama, com inteira razão, a pobreza do nosso cardápio. [...] estivemos algum tempo em acampamento americano e observamos a enorme variedade dos pratos ali servidos [...] Esse negócio de se ter na marmita sempre a mesma coisa já está ficando de amargar". ${ }^{79}$

O Cobra era impresso em tipografias e oficinas italianas. O primeiro número foi lançado em 17 de agosto de 1944, no acampamento de Tarquínia, quase 5 meses antes de O Cruzeiro do Sul, jornal do Serviço Especial da FEB, órgão do comando.

Teve 14 números ao total. Seu diretor e redatores eram militares combatentes do $1^{\circ}$ batalhão do $6^{\circ} \mathrm{Rl}$. O diretor era o tenente R2 José Alfio Piason, os redatores eram o cabo Higino, soldado Vidigal e soldado Dalcio, o secretário era o cabo Catani e a impressão responsabilidade do soldado Gaspar. ${ }^{80}$ Era, portanto, organizado por um oficial subalterno da reserva e cinco praças. Piason foi um dos autores do livro de depoimentos dos oficiais da reserva. As praças do jornal podiam ter experiência civil como tipógrafos ou gráficos.

Todos febianos podiam escrever, apesar de o jornal afirmar que a sede da redação ficava "nas barbas do tedesco" [próximo ao alemão], de o telefone "estar com defeito" (com o fio sempre cortado pelas explosões da artilharia alemã), que as oficinas ficavam "aqui, ali" (mudando de posição frequentemente), e a caixa postal era "de mão em mão" literalmente, ${ }^{81}$ não havendo, portanto, nenhuma dificuldade, bastava entregar a colaboração por escrito ao cabo Catani. ${ }^{82}$

O jornal era autofinanciado como registrado nesse agradecimento: "Agradecemos aos srs. oficiais e às praças da C.C. 1 que nos enviaram valiosa

79 E a Cobra Fumou!, n. 7, p. 2

80 Ibidem, n. 9, p. 2.

81 Ibidem.

82 Ibidem, n. ${ }^{6}$, p. 3. 
contribuição, para o engrandecimento e custeio de nossa folha". ${ }^{83} \mathrm{O}$ Cobra reunia características muito similares aos jornais feitos por estudantes, trabalhadores, sindicatos e partidos políticos. O correspondente dos Diários Associados, Joel Silveira, afirmou que $E$ a Cobra Fumou era "um jornalzinho rebelde, que às vezes traz excelentes e equilibrados comentários." 84

A partir do sexto número do jornal (10 nov. 1944), passou a figurar a afirmação" não registrado no DIP". ${ }^{85}$ Não ser censurado ainda virou piada: "Informa-se nesta cidade [...] os jornais do Brasil vão se dirigir ao seu importante colega 'E a Cobra Fumou' felicitando-o calorosamente pelo fato de ser o único jornal que circula sem ser registrado no DIP" ${ }^{86}$

Questões políticas eram apresentadas de maneira recorrente. No primeiro número, um artigo atestou que "o pavilhão brasileiro foi plantado nas terras da Itália; e seus soldados [...] conscientes de que lutam pelos direitos mais sagrados do homem: liberdade de dizer o que se pensa, liberdade de se crer num Deus, liberdade de não se sofrer temor"87, mesmo considerando que durante a ditadura Vargas havia censura e polícia política, que caçava seus opositores.

Na mesma edição, a coluna Dizem que... completou: "as eleições no Brasil se devem à FEB". Isso ocorreu antes do anúncio da reforma constitucional que regulamentava partidos e as eleições de 1945. Os febianos estavam conscientes de que lutar ao lado das potências democráticas pelo fim do nazifascismo, sem ter democracia em casa, era uma contradição insustentável. Sentiam que contribuíam para a causa democrática no Brasil. Ante esse sentimento, o tenente R2 Demócrito relembrou que os militares profissionais não apoiavam essa ambiente politizado:

Por instruções ainda de cima, os diretores dos pequenos jornais
em circulação nos regimentos (o precursor deles foi $E$ a Cobra
fumou! no 60RI) foram chamados ao gabinete do comando e
gravemente admoestados sobre o aparecimento de comentários
políticos. Felizmente, as coleções desses jornais foram guardadas
para se avaliar a origem desses ingênuos temores; mas naqueles
dias, inadvertido ainda sobre a evolução interna do país, era dessa
forma que o comando dava mostras do seu espírito
'democrático'. ${ }^{88}$

83 E a Cobra Fumou!, n. 6, p. 3.

84 SILVEIRA, Joel. O inverno da guerra. Rio de Janeiro: Objetiva, 2005. p. 40

85 E a Cobra Fumou!, n. 6, p. 1.

86 Ibidem, n. 8, p. 6.

87 Ibidem, p. 1.

88 ARRUDA, op. cit., p. 69-70. 
O próprio futuro dos convocados depois da guerra era debatido no jornal:

[...] considerando os problemas que o regresso do combatente sugere [...] é evidente que a maioria se verá a braços com dificuldades impostas pelo longo afastamento da vida civil, dificuldades tanto maiores quanto menor a iniciativa do indivíduo. A criação de departamentos que se propuzessem auxiliar o expedicionário nesse período de readaptação é uma necessidade. Estamos vencendo a guerra. A vitória, nós a levaremos para o Brasil. Se, na razão direta do que estamos realizando em outras terras, surgirem na nossa, iniciativas em prol da coletividade, veremos não ter sido em vão nosso sacrifício. ${ }^{89}$

\section{Considerações finais}

A participação da FEB na Segunda Guerra Mundial constituiu um momento de quebra de fronteiras entre o mundo militar típico do Exército de Caxias e o mundo civil. A FEB foi o palco dessa anomalia, com milhares de trabalhadores que se tornaram militares por um tempo. Esses trabalhadores militares foram comandados por um oficialato profissional. As experiências transformadoras a que foram submetidos na guerra resultaram na formação de uma consciência febiana, na defesa de seus valores e interesses.

Os febianos estabeleceram uma diferenciação prática entre nós e eles, nas tensões cotidianas com os militares profissionais do comando. Criaram mecanismos e instrumentos de agência para organizar e reforçar suas posições na luta. Sua ânsia para que a FEB fosse um modelo para reformular o Exército de Caxias pode ter sido uma das causas da desmobilização sumária da FEB, antes do retorno ao Brasil.

89 E a Cobra Fumou!, nำ6, p. 1 
Anexo 1 - Tabela: Profissões dos expedicionários de acordo com a cor da pele

\begin{tabular}{|c|c|c|c|c|c|c|c|}
\hline Preta & Qtd. & Morena & Qtd. & Parda Escuro & Qtd. & Parda & Qtd. \\
\hline Lavrador & 15 & Comerciário & 3 & Comerciário & 12 & Lavrador & 26 \\
\hline Operário & 11 & Lavrador & 3 & Operário & 9 & Operário & 16 \\
\hline Comerciário & 7 & Motorista & 3 & Carpinteiro & 6 & Comerciário & 13 \\
\hline Motorista & 5 & Agricultor & 1 & Pedreiro & 6 & Agricultor & 11 \\
\hline Mecânico & 4 & Doceiro & 1 & Lavrador & 4 & Mecânico & 6 \\
\hline Func. Público & 2 & Ferroviário & 1 & Agricultor & 4 & Motorista & 4 \\
\hline Pedreiro & 2 & Func. Público & 1 & Mecânico & 4 & Pedreiro & 4 \\
\hline Bombeiro & 2 & Carpinteiro & 1 & Func. Público & 2 & Func. Público & 3 \\
\hline Alfaiate & 1 & Lustrador & 1 & Motorista & 2 & Omitido & 3 \\
\hline Gráfico & 1 & Barbeiro & 1 & Padeiro & 2 & Alfaiate & 2 \\
\hline Lustrador & 1 & Operário & 1 & Omitido & 2 & Aux. de Lab. & 2 \\
\hline Tipógrafo & 1 & Pedreiro & 1 & Sapateiro & 2 & Marceneiro & 2 \\
\hline Carpinteiro & 1 & Pintor & 1 & Açougueiro & 1 & Rádio telegraf. & 2 \\
\hline Ferroviário & 1 & Sapateiro & 1 & Marítimo & 1 & Barbeiro & 1 \\
\hline Agricultor & 1 & Total & 20 & Desenhista & 1 & Carpinteiro & 1 \\
\hline Estudante & 1 & & & Encanador & 1 & Confeiteiro & 1 \\
\hline Op.Cinema & 1 & & & Lustrador & 1 & Contador & 1 \\
\hline Padeiro & 1 & & & Niquilador & 1 & Esmerilhador & 1 \\
\hline Servente & 1 & & & Vidreiro & 1 & Ferreiro & 1 \\
\hline Cozinheiro & 1 & & & Remador & 1 & Guarda Civil & 1 \\
\hline \multirow[t]{7}{*}{ Total } & 60 & & & Ferroviário & 1 & Laminador & 1 \\
\hline & & & & Músico & 1 & Lustrador & 1 \\
\hline & & & & Torn. Mecânico & 1 & Pescador & 1 \\
\hline & & & & Vulcanizador & 1 & Sapateiro & 1 \\
\hline & & & & Jornaleiro & 1 & Tintureiro & 1 \\
\hline & & & & Marceneiro & 1 & Tipógrafo & 1 \\
\hline & & & & Total & 69 & Total & 107 \\
\hline
\end{tabular}


Anexo 1 - Tabela: Profissões dos expedicionários de acordo com a cor da pele

...continuação

\begin{tabular}{|c|c|c|c|c|c|c|c|}
\hline Parda Clara & Qtd. & Branca (Parte 1) & Qtd. & Branca (Parte 2) & Qtd. & Cor Omitida & Qtd. \\
\hline Comerciário & 19 & Comerciário & 169 & Criador & 2 & Omitido & 13 \\
\hline Lavrador & 19 & Lavrador & 130 & Fazendeiro & 2 & Comerciário & 2 \\
\hline Operário & 15 & Agricultor & 67 & Marítimo & 2 & Ambulante & 1 \\
\hline Motorista & 9 & Operário & 64 & Op. cinema & 2 & Eletricista & 1 \\
\hline Agricultor & 7 & Estudante & 47 & Professor & 2 & Encanador & 1 \\
\hline Func. Público & 7 & Omitido & 30 & Relojoeiro & 2 & Lavrador & 1 \\
\hline Mecânico & 5 & Mecânico & 29 & Seleiro & 2 & Motorista & 1 \\
\hline Sapateiro & 4 & Motorista & 28 & Serralheiro & 2 & Operário & 1 \\
\hline Eletricista & 3 & Func. Público & 23 & Tecelão & 2 & Total & 21 \\
\hline Estudante & 3 & Alfaiate & 12 & Tipógrafo & 2 & & \\
\hline Pintor & 3 & Carpinteiro & 12 & Profissional Liberal & 1 & & \\
\hline Bombeiro & 2 & Pedreiro & 12 & Aeroviário & 1 & & \\
\hline Carpinteiro & 2 & Escriturário & 10 & Ajud. de Ambulatório & 1 & & \\
\hline Omitido & 2 & Bancário & 9 & Ajud. Prático Instal. & 1 & & \\
\hline Pedreiro & 2 & Eletricista & 8 & Balconista farmácia & 1 & & \\
\hline Tintureiro & 2 & Padeiro & 7 & Barcadista & 1 & & \\
\hline Alfaiate & 1 & Ferroviário & 6 & Bombeiro & 1 & & \\
\hline Barbeiro & 1 & Sapateiro & 6 & Caldeireiro & 1 & & \\
\hline Ferrador & 1 & Pintor & 5 & Canteiro & 1 & & \\
\hline Ferreiro & 1 & Aux. de farmácia & 4 & Cantor & 1 & & \\
\hline Ferroviário & 1 & Gráfico & 4 & Condutor de Bonde & 1 & & \\
\hline Foguista & 1 & Marceneiro & 4 & Soldador & 1 & & \\
\hline Litógrafo & 1 & Policial civil & 4 & Criado & 1 & & \\
\hline Lustrador & 1 & Rádio telegraf. & 4 & Datilógrafo & 1 & & \\
\hline Marceneiro & 1 & Advogado & 3 & Desenhista & 1 & & \\
\hline Marmorista & 1 & Aux. de Escritório & 3 & Encadernador & 1 & & \\
\hline Professor & 1 & Contador & 3 & Encanador & 1 & & \\
\hline Torn. Mecânico & 1 & Ferreiro & 3 & Estampador & 1 & & \\
\hline \multirow[t]{3}{*}{ Total } & 116 & Torn. Mecânico & 3 & Fiandeiro & 1 & & \\
\hline & & Barbeiro & 2 & Outros & 17 & & \\
\hline & & Caixeiro & 2 & Total & 769 & & \\
\hline
\end{tabular}

Fonte: AHEx, acervo FEB, baseado numa série de 1.162 Certificados de Reservistas

Recebido em 26/07/2019

Aprovado em 13/10/2019 